\title{
Д.В. Солдатенкова
}

Институт археологии РАН ул. Дмитрия Ульянова, 19, Москва, 117036, Россия E-mail: soldatenkova1961@yandex.ru

\section{СЕМАНТИКА ОРНАМЕНТА ВЫШИВКИ СЕВЕРОРУССКОГО ГОЛОВНОГО УБОРА ИЗ ФОНДОВ ГОСУДАРСТВЕННОГО МУЗЕЯ-ЗАПОВЕДНИКА «ЦАРИЦЫНО»}

Вводится в научный оборот новый музейный предмет, хранящийся в фондах Государственного музея-заповедника «Царицыно»,- женский головной убор - кокошник с редкой орнаментальной композицией, вышитой серебряными нитями. Кокошник атрибутируется по аналогии с опубликованным ранее головным убором из Новгородской губернии, датируемым рубежом XVIII-XIX вв., дается общее описание формы, декора предмета и техники вышивки. Раскрывается смысловое содержание (семантика) вышитой композиции в целом, которая представляет собой вертикальную модель Вселенной. Обозначены особенности русского варианта этого изображения, отличающемся тем, что центральная ось состоит из трех основных мотивов - цветущего мирового древа, солнечной богини Макоши с опущенными руками и древнего русского солнечного мотива орлиной ладьи. Верхний мир на северорусском головном уборе занимает половину изображения и наполнен солярными небесными мотивами, расположенными геральдически. Особенно интересен и архаччен среди них мотив лося-коня. Высказано предположение, что головной убор принадлежал молодой женщине до рождения первого ребенка, а возможно, был и венчальным, так как главная составляющая всего изображения сосредоточена вокруг идеи плодородия, изобилия, благопожелания.

Ключевые слова: вертикальная модель Вселенной, символ, знак, мотив вышивки, техника вышивки, стиль вышивки, мировое древо, пряхи, лоси-кони, птицы павы, двуәлавый орел, птица сирин, вышивка вприкреп по карте.

DOI: $10.20874 / 2071-0437-2016-32-1-123-132$

\section{Введение}

Несколько лет назад в фонд традиционного текстиля Государственного музея-заповедника «Царицыно» поступила деталь женского головного убора с очень редкой архаичной вышивкой (инв. № КП-13665, ТИ-1803). Мелкие, вышитые серебряной пряденой нитью и условно трактованные зооморфные мотивы выстроены в интересную геральдическую композицию, похожую на вертикальную модель Вселенной еще индоевропейской общности. Значение каждого мотива в отдельности, за редким исключением, известно, но каковы особенности русской модели? Почему орнамент может на протяжении многих веков хранить уходящие корнями в далекую древность представления о мироздании? Как «расшифровывается» каждый мотив в отдельности и о чем может «поведать» композиция в целом?

Изучение семантики орнамента северорусского шитья остается актуальным и по сей день. Это объясняется особенностями жизни традиционного орнамента во времени: в первую очередь его устойчивостью и каноничностью за счет сакральности изображаемого, из-за того, что он нес в себе важную для населения мифоологическую информацию, являясь так называемым иконическим знаком мифоопоэтической эпохи. Именно поэтому традиционный орнамент является историческим источником для изучения древних мифологических представлений восточнославянских и, впоследствии, русских племен.

Традиционный орнамент обладает многими функциями: знаковой, охранительной, благопожелательной, эстетической. Семантика орнамента непосредственно связана с его знаковой функцией. Выражение «знаковость или знаковая функция орнамента» требует пояснения. Орнамент скорее является символом, так как орнаментальные мотивы больше обрисовывают понятия, которые они обозначают, чем служат их произвольными, условными знаками. Символ «всегда не обозначение некоторого определенного содержания, а указание на смысловое поле, на определенную культурную традицию» [Барсуков и др., 1987, с. 86]. Орнаментальный мотив как простой символ обладает сложной многоплановостью и многозначностью. Ю.М. Лотман 


\section{Д.В. Солдатенкова}

приводит следующее определение: символ - знак, значением которого является некий знак другого ряда или другого языка $[1987$, с. 86]. Орнаментальные мотивы могут воспроизводить изображения зоо-, антропоморфные, растительные и т.д., которые, в свою очередь, символизируют представления о мироздании или какой-то ритуал, связанный с этими представлениями. Во многих случаях орнамент представлял «овеществленные» заклинания [Антонова, 1984, с. 200; Неклюдов, 1972, с. 216]. В орнаментах, как и в символах, очень важен иконический элемент.

В ходе исторического развития эстетическая функция орнамента начинает вытеснять знаковую. Под влиянием городской культуры в традиционном орнаменте происходят необратимые изменения и знаковая функция угасает к концу XIX В., когда в крестьянской вышивке излюбленными становятся брокаровские узоры в технике креста. Это были крупные цветочные орнаменты, которыми украшались обертки дешевой парфюмерной продукции немецкой фирмы «Брокар и Ко» (в основном мыла). В деревнях быстро распространились модные узоры, а традиционный орнамент вышивки ушел в прошлое.

Дольше всего знаковую функцию сохраняли именно женские головные уборы и соответственно их орнаментация. Связано это с тем, что, во-первых, они являлись наиболее консервативным элементом костюма благодаря той важной роли, которую играли в определении социального и половозрастного положения женщины (перемена головного убора являлась центральным моментом свадебного ритуала). Во-вторых, женский головной убор выполнял охранительную функцию, полностью закрывая волосы, которые были связаны с представлениями о жизненной силе, богатстве, плодородии и в разных формах могли использоваться в ритуальной практике [Гаген-Торн, 1933, с. 76; Мазалова, 2001, с. 49-52]. В-третьих, фрорма и декор головного убора были стойкими показателями этнической принадлежности. На то, что именно орнаменты на женских головных уборах несли особую знаковую нагрузку, указывает Г.С. Маслова, исследовавшая орнаментику их вышивки: «Наиболее оригинальные зооморфные мотивы карел отражены преимущественно в вышивках головных уборов. Головной убор отражал социальное положение женщины, в нем наиболее устойчиво сохранились древние орнаментальные мотивы; новые орнаментальные мотивы проникали сюда значительно реже, чем, например, в узоры полотенец» [1951, с. 127].

\section{Общее описание кокошника}

Объектом нашего исследования является тыльная деталь кокошника, бытовавшего в северовосточной части Новгородской губ. и в Каргопольском уезде Олонецкой губ., датируемая концом XVIII - началом XIX в. по аналогии с такой же деталью женского головного убора из Музея народного искусства (МХП 12908). Кокошник из Музея народного искусства происходит из Кирилловского уезда Новгородской губернии. Оба предмета имеют идентичные фрормы и размеры: первый, из фондов ГМЗ «Царицыно»,- 32 см (с очельем), 26 см (без очелья) $\times 20$ см; второй - 25×16 см. Их декорировка выполнена близкими орнаментальными мотивами характерным стилем вышивки металлической нитью [Дурасов, Яковлева, 1990, с. 175]. Цельный кокошник имел верх овальной формы, твердый подтреугольный выступ надо лбом, лопасти над ушами. Все детали кокошника обильно украшались золотосеребряной вышивкой, вышивкой колотым перламутром и речным жемчугом, на нижнюю часть твердого очелья нашивалась поднизь в виде присборенной решетки из речного жемчуга. В Олонецкой губернии предпочитали весь головной убор зашивать золотной нитью, отчего он становился светлым и сверкающим, на северо-востоке Новгородской губернии любили оставлять просветы темно-красного или малинового бархата [Молотова, Соснина, 1984, № 131]. Сзади у кокошника спускался на шею прямоугольный позатыльник; идентичные форму и декор имеет рассматриваемый нами предмет. Верхняя часть такого кокошника из фондов ГМЗ «Царицыно» - мягкая, на домотканой льняной подкладке идентичных фрормы и размеров. К прямоугольному краю пришито более позднее твердое очелье, о чем свидетельствует его белая хлопчатобумажная подкладка, полоса которой шириной 2,3 см видна на стыке очелья с верхней частью кокошника. Чужеродность очелья подтверждают другое качество нитей и ковровый стиль вышивки более тонкими золотными нитями оранжевого оттенка. Оно могло быть частью другого, более позднего головного убора - сборника, но никакого отношения к кокошнику не имело. Тем более что этот прямоугольный край являлся позатыльнем и сзади закрывал шею его владелице. Видимо, обе детали были соединены, когда износились остальные части и кокошника и сборника. Чтобы не нарушать историческую жизнь музейного предмета, реставраторы не стали разъединять две детали. 


\section{Семантика орнамента вышивки северорусского головного убора...}

Стиль вышивки зависит от техники ее исполнения, а также от материала, на котором вышивают, и от того, какими нитями выполняется работа. Кроме того, большую роль играет орнамент вышивки - растительный, как на нижегородских платках; геометрический, как на старинных тамбовских рубахах, или с преобладанием зооморфного и антропоморфного (т.е. изобразительного) орнамента, как на деталях этих кокошников. Имеет значение расположение зоо- и антропоморфных мотивов на ткани. На исследуемом музейном предмете их компоновка очень тесная, а сами мотивы мелкие, среди них много архаичных, иконография которых после XVIII в. встречается очень редко (таковы изображения богини Макошь, лосей-коней, Доли и Недоли, птиц сирин) (рис. 1). Из-за того, что мотивы мелкие и расположены близко друг к другу, они выполнены условно и упрощенно.

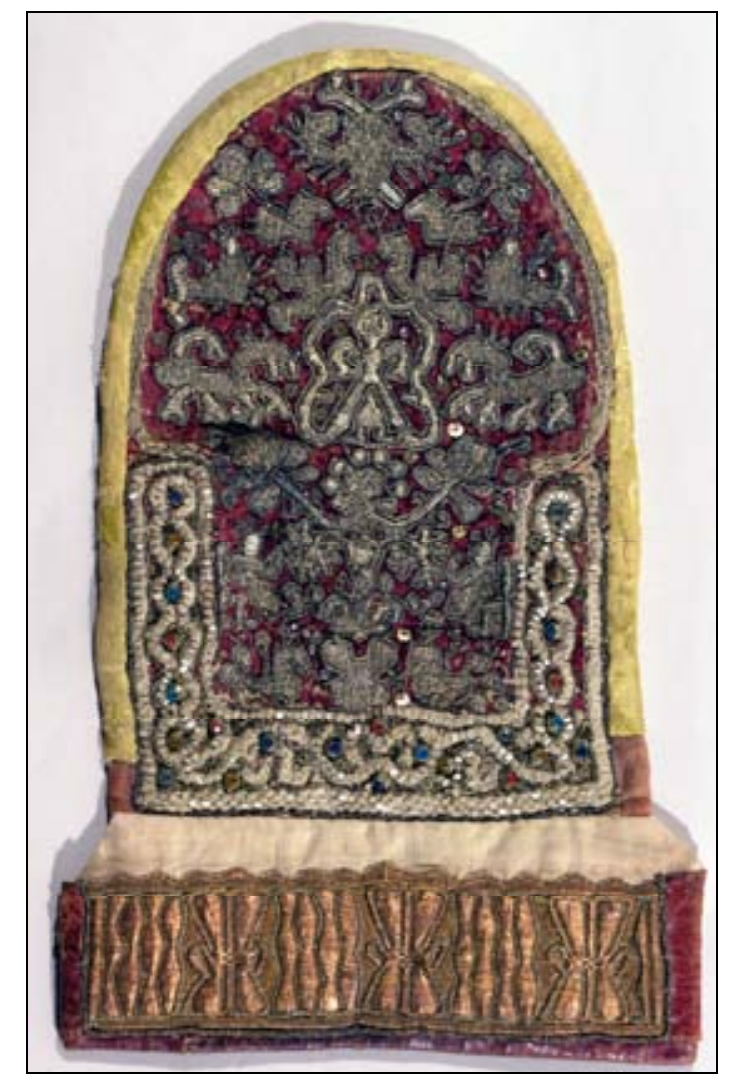

Рис. 1. Композиция вышивки в целом. Бархат, холст льняной домотканый, нити серебряные пряденые колотый перламутр, стразы, пайетки. Вышивка вприкреп по карте. Ткань хлопчатобумажная, картон, нити золотные пряденые, кожа. Вышивка вприкреп, шитье ручное.

На лицевой части кокошника пряденой серебряной нитью вприкреп по карте по красному бархату вышита геральдическая композиция, вытянутая по вертикали (рис. 1). Техника серебряного и золотного шитья вприкреп по карте является очень древним способом декорирования ткани. Она заключается в вырезании из картона или нескольких слоев бумаги орнаментальных мотивов, которые мастерица располагает на ткани согласно традиции. Затем на бумажный мотив, положенный с лицевой стороны ткани, накладывали серебряную или золотную нить в один ряд и тонкой шелковой или хлопчатобумажной нитью закрепляли с изнаночной стороны. Поэтому ткань дольше сохранялась, а вышитые таким способом узоры были ровными, блестящими и рельефрными.

Почти все мотивы вышивки оконтурены тонким серебряным жгутом. Между ними нашиты на бархат редкие пайетки и мелкие стеклянные стразы в металлической оправе. Верхняя часть детали кокошника имеет закругленную форму, а снизу - прямые углы и декорирована по трем краям пояском из двух извивающихся линий вышивки мелким колотым перламутром. В образованных овалах нашиты синие, желтые и красные стразы. К нижней части пришито узкое прямо- 


\section{Д.В. Солдатенкова}

угольное очелье, сплошь зашитое оранжевой золотной нитью и по узким сторонам украшенное сафьяном. Возможно, очелье имеет более позднее происхождение, судя по особенностям и фактуре вышивки и другого качества нитям. Очевидно, изначально это был кокошник, когда же он износился, его переделали в «сборник» с новым очельем и утраченными боковыми частями, сквозь нижнюю часть которых продевалась тесьма и завязывалась сзади. Самое важное, что вышитая верхняя часть головного убора осталась почти невредимой, лишь слегка потертой в месте горизонтального сгиба по центру, так как владелец хранил ее сложенной пополам.

Описание и анализ вышивки

Вертикальная модель вселенной у русских, как и у всех индоевропейских народов, делилась на верхний, средний и нижний миры. Центральной осью, центром мира и мироздания в целом является мировое дерево или древо жизни [Топоров, 1980, с. 398-406]. Образ мирового дерева означает разные вертикальные и горизонтальные координаты мироздания: в первом случае это дуб от земли до неба, а во втором - образ дороги, как в загадке «Когда свет зародился, тогда дуб повалился и теперь лежит». Мировое дерево отражает не только пространственные, но и временные координаты: «Стоит дуб, на дубу двенадцать сучьев, на каждом сучке по четыре гнезда...», т.е. говорится о годе, двенадцати месяцах, четырех неделях и т.д. [Петрухин, 2004, с. 253].

В русских заговорах мировое дерево помещается на острове среди океана (пуповине морской), где на камне Алатыре растет «булатный дуб» или священное дерево кипарис, береза или яблоня. В ветвях и на вершине дерева обитают божества и святые. В корнях мирового дерева (в нижнем мире) обитают демонические и хтонические существа - прикован бес, живет змея Шкурупея, плавают водоплавающие птицы, которые могут обитать во всех трех мирах [Там же].

Вышивка головного убора имеет трехчастную композицию, где центральная Ось Вселенной состоит из трех мотивов, расположенных один над другим. В нижней части композиции вышито цветущее дерево с явными антропоморфными чертами. У его основания размещены крупные листья, немногочисленные ветви направлены вверх, центральная ветвь или ствол оканчивается цветком-солнышком с восьмью лепестками. Изображение дерева несло большую смысловую нагрузку. B XVIII-XX вв., а возможно, и в более ранние времена у русских существовали священные деревья как объекты поклонения - отголоски почитания мирового дерева. Считалось, что они исцеляют от болезней, сглаза и бесплодия. Болящие приносили дары этим деревьям, поклонялись им, молились [Голубкова, 2009, с. 39-41]. На старые почитаемые деревья вешали кресты, образки, традиционно рядом с ними проводились различные обряды. «Например, вокруг дерева иногда "венчали" молодых (или предваряли этим церковный обряд венчания). Во время обхода полей с крестным ходом священник с прихожанами совершали возле священного дерева (обычно дуба или плодового дерева) молебен от града и засухи, здесь же устраивали праздничные трапезы, жгли костры на масленицу; вблизи священного дерева освящали воду, крестили детей, давали клятвы и устраивали суды» [Шапарова, 2001, с. 229].

На вышивке кокошника по бокам от мирового дерева с обращенными к нему лицами изображены сидящими на стульях Доля и Недоля или Среча и Несреча - две сестры, помощницы Макоши - «девы судьбы, пряхи, прявшие нить жизни каждого человека, его счастливую или злую судьбу» [Там же, с. 231] (рис. 2). Долю представляли как красивую молодую девушку пряху, прядущую ровную, золотистую нить счастливой судьбы. Противоположностью Доли была Недоля, прядущая нить судьбы плохую, несчастливую. Доля и Недоля изображены на детали кокошника очень условно, без прялок, но в позах, показывающих, что они прядут со ствола или с нижних ветвей священного дерева. Это предположение доказывают многие обряды прядения с печного столба, имевшегося в каждой избе,- олицетворения мирового дерева в домашнем микрокосме. У русских нить была окружена благоговейным отношением, особенно льняная. Представление о прядении нити, воплощающей судьбу, жизнь, долю, восходит к индоевропейской древности - образам мифологических прях у мирового древа (ср. болгарских орискиц, сербскую Сречу, которая прядет золотую нить.). В славянской традиции фрункциями прях, определяющих судьбы, наделяются как высшие персонажи, в том числе Богородица, св. Варвара, Параскева Пятница - покровительницы рожениц и прях, так и низшие, например кикимора. Кикимора с мокошей наказывала прях, оставлявших не убранную на ночь кудель или прядущих в праздник. Изготовленная же в праздник - Великий четверг оборотная нить, которую пряли, вращая веретено от себя или «наотмашь», считалась оберегом [Там же, с. 231]. 


\section{Семантика орнамента вышивки северорусского головного убора...}

Среди многих обрядов, связанных с нитью и прядением с печного столба, Г.С.Маслова отмечает бытовавший в Саратовской губернии. «Отправляясь к жениху с подарками, подруги невесты обязательно присоединяли к ним суровую нитку»; изготавливала ее тайком невеста на печном столбе особым способом «наотмашь», вращая веретено в левую сторону, сучила также «наотмашь», завязывала на ней шесть узлов и половинку сакральной нити оставляла себе, другую отдавала жениху [Маслова, 1984, с. 37-38]. Прядение нити, как священный акт, в славянской традиции приравнено к творению жизни и воспроизводству потомства [Валенцова, 2009, с. 328].

Верхняя половина детали головного убора (верхний мир) наполнена небесной и солнечной символикой. На вершине цветущего мирового дерева изображена традиционная для всей северорусской вышивки архаичная композиция: богиня Макошь с солнечными лосями-конями по бокам - излюбленный мотив на вышитых полотенцах, подзорах, подолах рубах. Солнце у славян издревле было связано с женским божеством плодородия. На голове у Макоши изображен круглый солнечный ореол, руки ее опущены - таким образом она всегда изображалась в дни летнего солнцестояния, когда созревают колосья злаков [Рыбаков, 1994, с. 521-522] .

Солнечная богиня вышита в блестящем ореоле - ее изображение обрамлено полосой из блестящих серебряных нитей, что олицетворяет тепло и свет. Наверху над головой богини ореол заканчивается рогом. Лучи-рога восходят к раннеземледельческому культовому символу плодородия и женского начала. На детали кокошника солнце изображено в самый разгар созревания злаков: богиня Макошь представлена с опущенными к земле руками, ведь солнце является творцом урожаев. «Не земля хлеб родит, а небо», «Лето родит, а не поле» - говорила народная мудрость [Дурасов и др., 1990, с. 16]. На ореоле над плечами богини вышиты две крылатые солнечные ладьи - излюбленные в северорусской вышивке мотивы.

Следующие мотивы изображены геральдически по отношению к солнечной богине, начиная с лосей-коней и заканчивая птицами павами. Считается, что конь заменил оленя или лося не только в качестве существа, ведущего в загробный мир. Древнейший миф о солнечном олене (лосе) привел к представлению о солнечном коне. В мифах индоевропейских и некоторых других народов, в том числе на Древнем Востоке, конь перевозит солнечного бога, а иногда и сам ассоциируется с солнцем. В Авесте солнце называется «быстроконным» [Голан, 1994, с. 49]. В Ригведе говорится о солнце, влекомом лошадьми, конь выступает в качестве образа солнца. В Иране изображение лошади понималось как олицетворение солнечного божества Митры [Там же]. Как считает А. Голан, в древних верованиях конь, как и олень (лось), был связан с загробным миром и солнцем [1994, с. 50-51]. Славянское предание гласит, что солнце разъезжает по небу на подобных птицам крылатых конях, кроме того, кони, которых держит под уздцы солнечная богиня, символизировали вечернюю и утреннюю зарю. Солнечные кони в народном представлении - существа франтастические: шерсть у этих «сивок-златогривок» серебряная, хвост и грива золотые - «золотая шерстинка, серебряна щетинка», «из ноздрей пламя пышет, искры летят» [Дурасов и др., 1990, с. 16]. На детали головного убора кони выполнены в очень архаичной манере - морды у них раздвоенные (с открытыми ртами), хвосты загнуты вверх к спинам, копыта раздвоены. Лоси-кони на музейном предмете имеют редкую иконографию: они изображены вставшими на дыбы, в движении, с поднятыми передними ногами - видимо, это очень древняя традиция. На детали кокошника вышита архаическая переходная форма лось-конь. Подобной иконографии мифологические животные - с раскрытыми ртами, раздвоенными копытами, завитками на голове, возможно символизировавшими рудименты рогов, достаточно редко, но все же встречаются в северорусском шитье полотенец [Рыбаков, 1994, с. 78-85] (рис. 2).

Над солнечными конями вышиты мифические птицы сирин - жительницы заоблачного вырия - рая. Разобраться, что это именно они, помогло внимательное рассмотрение их голов, аналогичных вышитым лицам Доли и Недоли. Это овальные головки, повернутые к зрителю, с несколькими завитками, имитирующими волосы. Считается, что райские птицы сирин с прекрасными женскими лицами попали в народную культуру довольно поздно вместе с лубочными картинками (рис. 3) [Дурасов и др., 1990, с. 21]. Они обладали специфическими раздвоенными хвостами, которые на лубочных картинках окружались пышным оперением, а в вышивке изображались очень условно, с передачей самых главных черт. Предания же о них возникли на основе представлений о птицедевах - вилах, а частично на основе легенд о мифической птице Стратим, упоминаемой в стихах о Голубиной книге. Согласно этим стихам, Стратим, как и алконост, «детей производит на окиане-море» и при этом обладает властью над погодой: от ударов ее крыл рождаются ветры и поднимается буря» [Шапарова, 2001, с. 25]. 


\section{Д.В. Солдатенкова}

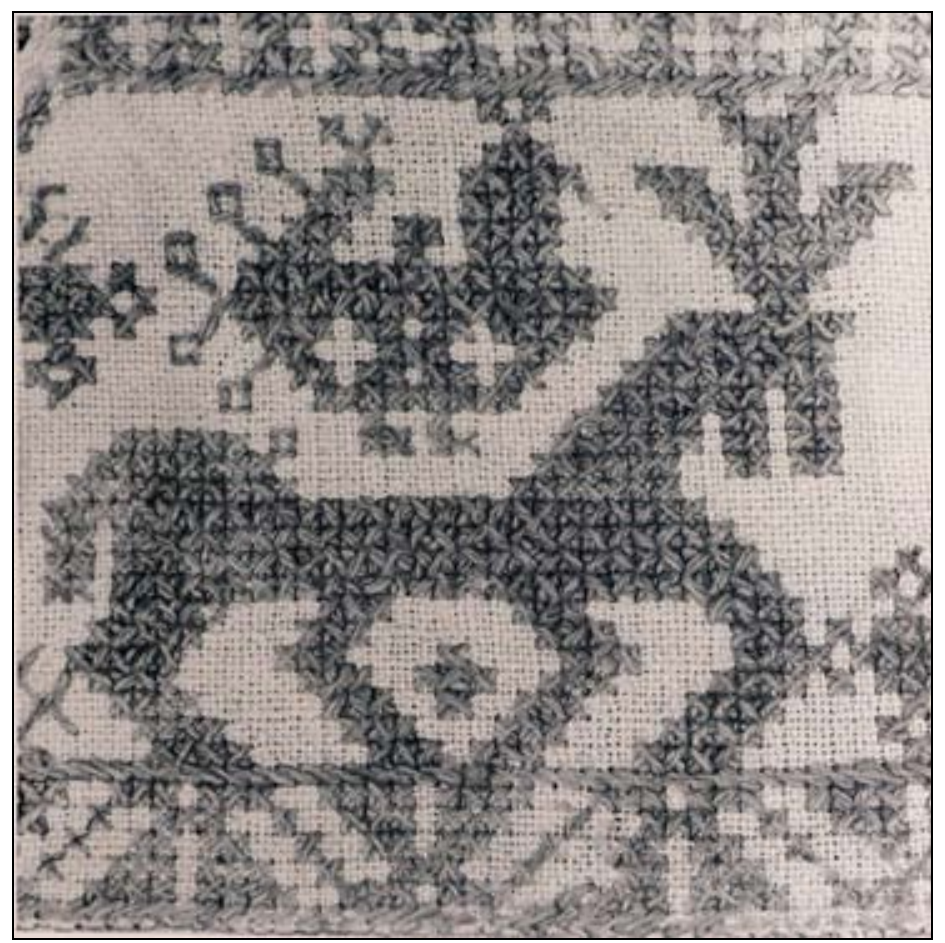

Рис. 2. Деталь вышитого передника с мотивом лося-коня. Вышивка: крест, стебельчатый шов. МХП 22046. (по: [Дурасов, Яковлева, 1990, с. 74]).

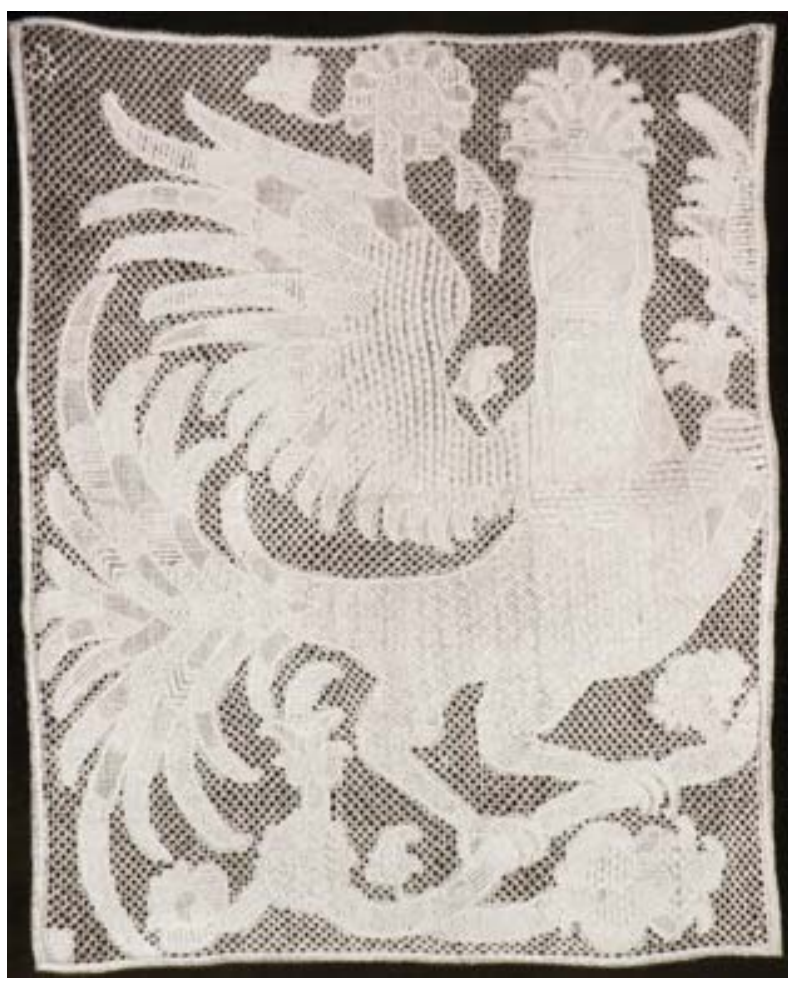

Рис. 3. Деталь полотенца с мотивом птицы сирин. Вышивка: белая строчка и шов по письму. МХП 11982. (по: [Дурасов, Яковлева, 1990, с. 134]). 


\section{Семантика орнамента вышивки северорусского головного убора...}

Над птицами сирин на кокошнике вышиты две птички - павы с веерообразными процветшими круглыми хвостами, ведущие происхождение от павлинов со сказочно красивыми хвостами. Они символизировали небесный «белый» свет и пожелание плодородия. Такие символы часто встречаются в вышивке северорусских полотенец, их любили вышивать в технике цветной перевити и на закрытых калужских и орловских передниках и полотенцах, где они были гораздо крупнее, чем в северном двустороннем шитье. Кроме того, образ птицы-павы был связан с солнцем: жар-птица летит по небу над землей и роняет из своего хвоста перья-лучи [Дурасов, Яковлева, 1990, с. 15].

Над всей композицией главенствует двуглавый орел. В XVIII в., которым датируется рассматриваемая деталь кокошника, он вполне мог ассоциироваться в народном сознании с гербом Российской империи, но в вышитую композицию попал совсем не случайно. Как было сказано в начале статьи, традиционный орнамент очень устойчив, особенно в вышивке головных уборов. Его мотивы продолжают вышивать, даже когда их первоначальный смысл уже забыт. Первоначально орел в народном сознании был воплощением небесного огня и солнца. Изображенные на кокошнике два орла срастаются в одну двуголовую птицу — солнечную «птичью» ладью.

Мотив двуглавого орла был известен восточному славянству еще на заре его исторической жизни [Рыбаков, 1994, с. 484] (рис. 4). И даже когда он приобретает черты, близкие к Московскому гербу, в народных вышивках он присутствует не как государственная эмблема, а как новый извод привычного народного мотива (рис. 5). Орел, как одиночный, так и двуглавый, довольно часто встречается в вышивке северорусских полотенец, где он выполнялся красными льняными нитями в технике двустороннего шитья, олицетворяя солнечный свет, тепло, небесный огонь.

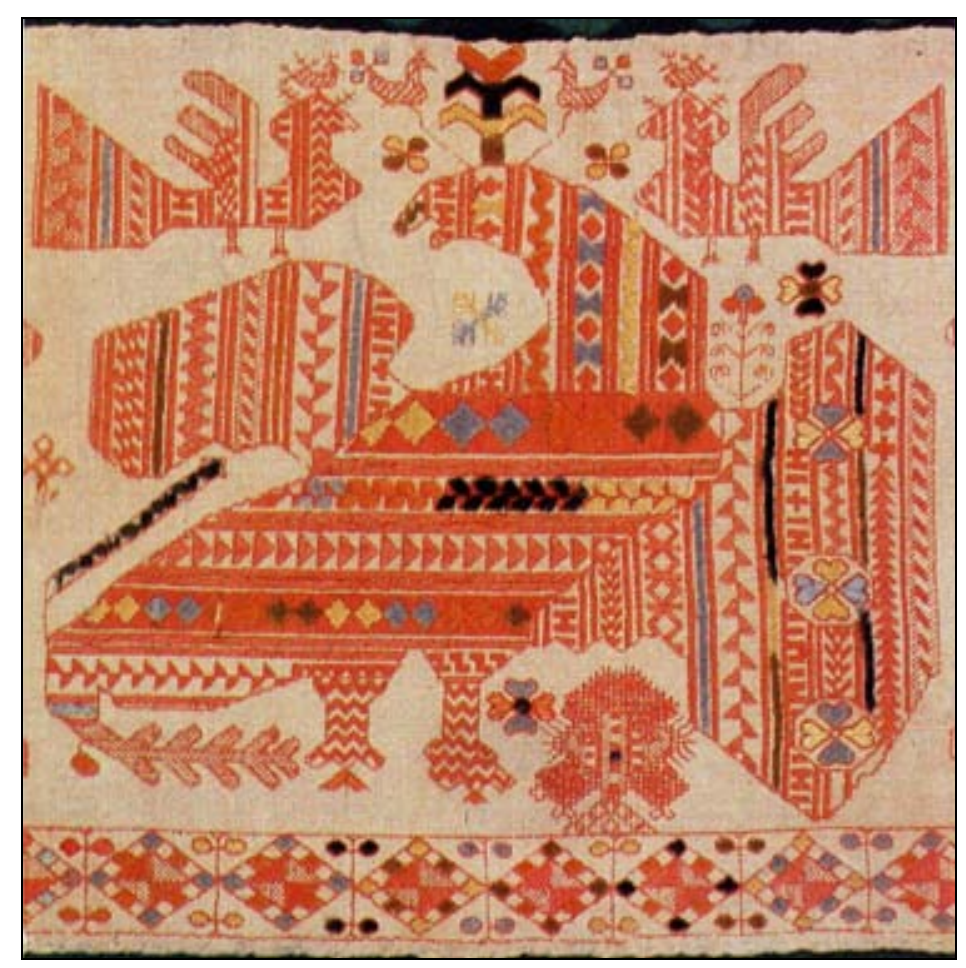

Рис. 4. Деталь полотенца с мотивом орла. Вышивка: набор, гладь, роспись по домотканому холсту. МХП 11769 (по: [Дурасов, Яковлева, 1990, с. 113]).

Вышивка на детали женского головного убора кокошника из фондов музея «Царицыно» вся пронизана символикой света, благопожелания, плодородия. Немаловажную роль играет сам цвет вышивки: ее красный фон олицетворяет огонь, к которому в народе было особое отношение - его называли «батюшка ты, Царь-огонь». Огонь означал оживление, здоровье, воскресение, начало жизни. Верили, что красный цвет обладает чудесными свойствами, связывали его с плодородием [Касторский, 1841, с. 160]. 


\section{Д.В. Солдатенкова}

В серебряном цвете вышивки, олицетворяющем небесный «неосязаемый» свет, видели высочайшее благо и связывали с ним представления об изобилии и счастье [Афанасьев, 1865, с. 94-100]. С этим «неосязаемым» светом ассоциировался, кроме того, белый цвет льняного холста, зеркала, сосуды с водой, блеск золота и серебра, а также цвет и блеск серебряных и золотных нитей.

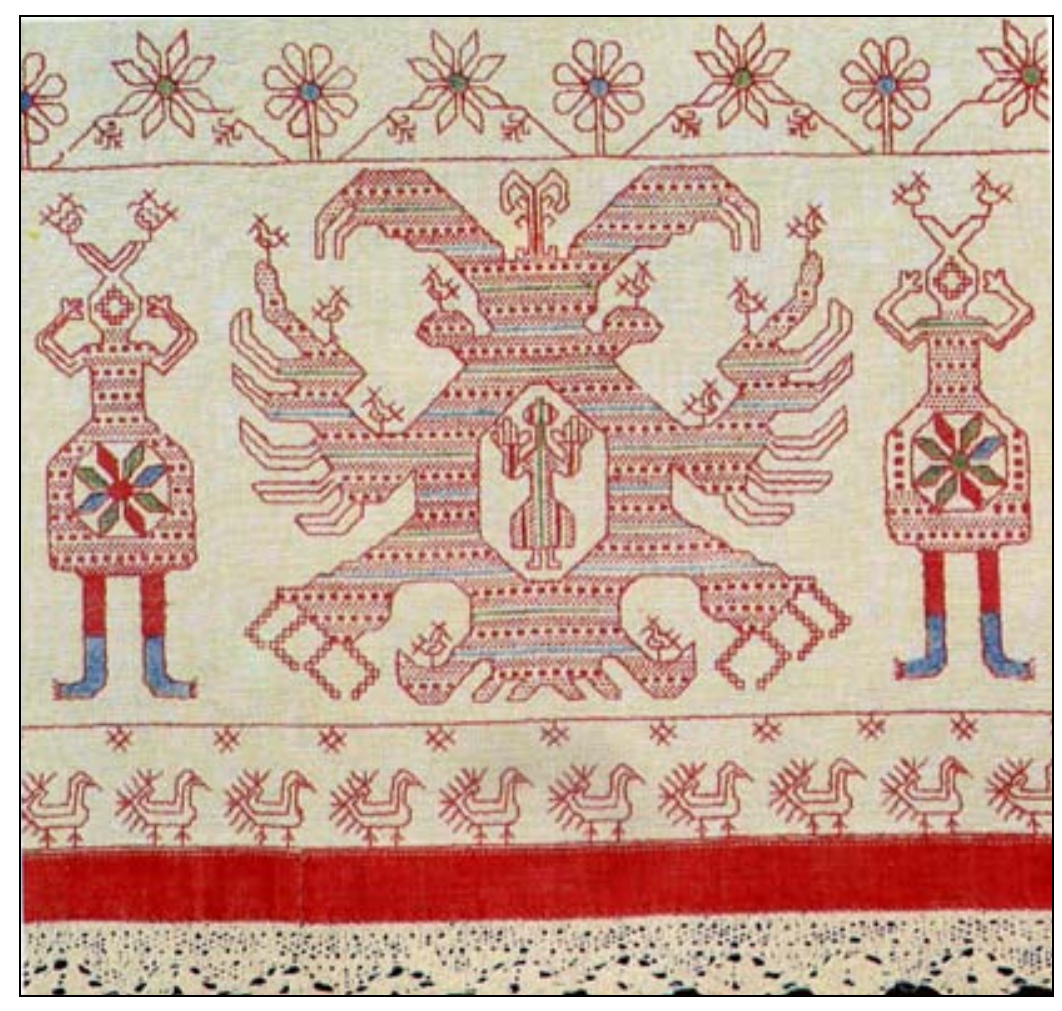

Рис. 5. Деталь подзора с мотивом двуглавого орла. Вышивка: роспись, набор, гладь по домотканому холсту. МХП 11872 (по: [Дурасов, Яковлева, 1990, с. 117]).

Символика вышивки верхней части северорусского кокошника говорит о том, что он принадлежал молодой женщине до рождения первого ребенка, а возможно, был и венчальным, так как главная составляющая всего изображения сосредоточена вокруг идеи плодородия, изобилия, благопожелания. Кроме того, можно говорить, что изображение вертикального строения вселенной, в основном верхнего мира, наполненного небесными и солнечными символами, вышивалось в женском костюме именно на головных уборах, так как голова ассоциировалась в человеческом микрокосме с верхним миром [Мазалова, 2001, с. 14-15].

\section{Заключение}

Рассмотрев семантику мотивов вышивки детали женского головного убора, можно сделать следующие выводы. Вся композиция в целом символизирует вертикальную модель Вселенной. Мировая ось состояла не из одного мирового древа, а из трех мотивов: мирового древа, солнечной богини и солнечной колесницы - ладьи из двух орлов, древнего русского символа света, огня, тепла. Вероятно, у русских модель Вселенной была тесно переплетена с природными солнечными циклами и изображалась, таким образом, вариативно, в зависимости от времени года. Большую роль в изображении русской модели играет солнечная богиня Макошь - магическое положение ее рук указывает на определенный момент времени года и состояние природы. На женском головном уборе модель Вселенной изображена во время летнего солнцестояния. Вероятно, головной убор принадлежал молодухе в детородном возрасте, так как главная составляющая всего изображения сосредоточена вокруг идеи плодородия, изобилия, благопожелания. 
Афранасьев А.Н. Поэтические воззрения славян на природу. М., 1865. Т. 1. 801 с. 266 c.

Антонова Е.В. Очерки культуры древних земледельцев Передней и Средней Азии. М.: Наука, 1984.

Барсуков С.Г., Гришакова М.Ф., Григорьева Н.Г., Зайони Л.О., Лотман Ю.М., Пономарева Г.М., Митрошкин В.Ю. Предварительные замечания по проблеме «Эмблема-символ-мифр в культуре XVIII столетия» // Труды по знаковым системам. Тарту: Изд-во Тартус. ун-та, 1987. Вып. 746. С. 85-94.

Валенцова М.М. Пряжа. // Славянские древности: Этнолингвистический словарь. / Под ред. Н.И. Толстого. М.: Междунар. отношения, 2004. Т. 4. С. 328-330.

Гаген-Торн Н.И. Магическое значение волос и головного убора в свадебных обрядах Восточной Европы // СЭ. 1933. № 5-6. С. 76-88.

Голан А. Мифр и символ. 2-е изд. М.: РУССлИТ, 1994. 375 с.

Голубкова О.В. Душа и природа: Этнокультурные традиции славян и финно-угров. Новосибирск: Издво ИАЭТ СО РАН, 2009. 304 c.

Дурасов Г., Яковлева Г. Изобразительные мотивы в русской народной вышивке. Музей народного искусства. М.: Изд-во Сов. Россия, 1990. 320 с.

Касторский М.Н. Начертание славянской мифологии. СПб., 1841.189 с.

Лотман Ю.М. Символ в системе культуры // Семиотика: Труды по знаковым системам: Символ в системе культуры. Тарту: Изд-во Тартус. ун-та, 1987. Вып. 754. С. 10-21.

Мазалова Н.Е. Состав человеческий: человек в традиционных соматических представлениях русских. СПб.: Петерб. востоковедение, 2001. 192 с.

Маслова Г.С. Историко-культурные связи верхневолжских карел по данным орнамента. М.: Наука, 1951. $158 \mathrm{c}$

Маслова Г.С. Народная одежда в восточнославянских традиционных обычаях и обрядах XIX - нач. XX вв. М.: Наука, 1984. 216 с.

Молотова Л.Н., Соснина Н.Н. Русский народный костюм из собрания Государственного музея этнографии народов СССР. Л.: Художник РСФСР, 1984. 225 с.

Неклюдов С.Ю. Особенности изобразительной системы в долитературном повествовательном искусстве // Ранние формы искусства. М.: Искусство, 1972. С. 191-220.

Петрухин В.Я. Мировое дерево // Славянские древности: Этнолингвистический словарь / Под ред.

Н.И. Толстого. М.: Междунар. отношения, 2004. Т. 3. С. 253-254.

Рыбаков Б.А. Язычество древних славян. М.: Наука, 1994. 608 с.

Топоров В.Н. Древо мировое // Мифы народов мира: Энцикл.: В 2 т. М.: Наука, 1980. Т. 1. С. $398-406$.

Шапарова Н.С. Краткая энциклопедия славянской мифологии. М.: АСТ: Астрель: Рус. словари, 2001. $624 \mathrm{c}$.

D.V. Soldatenkova

Institute of archaeology of the RAS

Dm. Ul'ianov, 19, Moscow, 117036, Russian Federation

E-mail: soldatenkova1961@yandex.ru

\section{SEMANTICS OF AN ORNAMENT OF AN EMBROIDERY OF THE NORTH RUSSIAN HEADDRESS FROM FUNDS OF THE STATE MUSEUM RESERVE «TSARITSYNO»}

The article introduces an item from funds of the State museum «Tsaritsyno» - a female headdress kokoshnik with the rare ornamental composition embroidered with silver threads. The details of the kokoshnik are attributed by analogy with the published earlier similar part of a headdress from Novgorod, dated with a turn of XIX century. General description of a form, decor of the item and embroidery technique are presented. The embroidered composition represents in general a vertical model of the Universe. Russian version of this image includes the central axis consists of three main motives - the blossoming world tree, of the solar goddess Makosha with the lowered hands and ancient Russian solar motive of two-headed eagle. The top world on a headdress occupies a half of the image which is filled with solar heavenly motives (located heraldic). The motive of an elkhorse is especially interesting and archaic among them. It is suggested that the headdress belonged to the young woman till the birth of her first child, perhaps, was also used in course of wedding because all images are connected to ideas of fertility, abundance, good wishes.

Key words: vertical model of the Universe, symbol, sign, motive of an embroidery, embroidery technique, embroidery style, world tree, elk-horse, birds of a peahen, two-headed eagle, bird of sirens.

DOI: $10.20874 / 2071-0437-2016-32-1-123-132$ 


\section{Д.В. Солдатенкова}

\section{REFERENCES}

Afanas'ev A.N., 1865. Poeticheskie vozzreniia slavian na prirodu [Poetic views of Slavs on the nature], vol. 1, Moscow, $801 \mathrm{p}$.

Antonova E.V., 1984. Ocherki kul'tury drevnikh zemledel'tsev Perednei i Srednei Azii [Sketches of culture of ancient farmers of Forward and Central Asia], Moscow: Nauka, 266 p.

Barsukov S.G., Grishakova M.F., Grigor'eva N.G., Zaionts L.O., Lotman lu.M., Ponomareva G.M., Mitroshkin V.Iu., 1987. Predvaritel'nye zamechaniia po probleme «Emblema-simvol-mif v kul'ture XVIII stoletiia». Trudy po znakovym sistemam [Works on sign systems], Tartu: Izd-vo Tartuskogo un-ta, 746, pp. 85-94.

Gagen-Torn N.I., 1933. Magicheskoe znachenie volos i golovnogo ubora v svadebnykh obriadakh Vostochnoi Evropy [Magic value of hair and headdress in wedding ceremonies of Eastern Europe]. Sovetskaia etnografiia, no. 5-6, pp. 76-88.

Golan A., 1994. Mif i simvol [Myth and symbol], 2-e izd, Moscow: Russlit, 375 p.

Golubkova O.V., 2009. Dusha i priroda: Etnokul'turnye traditsii slavian i finno-ugrov [Soul and nature: Ethnocultural traditions of Slavs and finno-ugr], Novosibirsk: Izd-vo Instituta arkheologii i etnografii SO RAN, 304 p.

Durasov G., lakovleva G., 1990. Izobrazitel'nye motivy $v$ russkoi narodnoi vyshivke. Muzei narodnogo iskusstva [Graphic motives in the Russian national embroidery. Museum of folk art]. M.: Sovetskaia Rossiia, 320 p.

Kastorskii M.N., 1841. Nachertanie slavianskoi mifologii [Tracing of Slavic mythology], St. Petersburg, 189 p.

Lotman lu.M., 1987. Simvol v sisteme kul'tury. Semiotika: Trudy po znakovym sistemam: Simvol v sisteme kul'tury [Semiotics: Works on sign systems: A symbol in system of culture], 754. Tartu: Izd-vo Tartuskogo universiteta, pp. 10-21.

Mazalova N.E., 2001. Sostav chelovecheskii: Chelovek v traditsionnykh somaticheskikh predstavleniiakh russkikh [Structure human: The person in traditional somatic representations of Russians], St. Petersburg: Peterburgskoe vostokovedenie, $192 \mathrm{p}$.

Maslova G.S., 1951. Istoriko-kul'turnye sviazi verkhnevolzhskikh karel po dannym ornamenta [Historical and cultural communications Upper Volga the Karelian according to an ornament], Moscow: Nauka, $158 \mathrm{p}$.

Maslova G.S., 1984. Narodnaia odezhda $v$ vostochnoslavianskikh traditsionnykh obychaiakh $i$ obriadakh $X I X$ - nach. XX vv. [National clothes in East Slavic traditional customs and ceremonies of XIX — the head of the $X X$ centuries], Moscow: Nauka, 216 p.

Molotova L.N., Sosnina N.N., 1984. Russkii narodnyi kostium iz sobraniia Gosudarstvennogo muzeia etnografii narodov SSSR [The Russian national suit from the collection of the State Museum of ethnography of the people of the USSR], Leningrad: Khudozhnik RSFSR, 225 p.

Nekliudov C.lu., 1972. Osobennosti izobrazitel'noi sistemy v doliteraturnom povestvovatel'nom iskusstve. Rannie formy iskusstva [Early forms of art], Moscow: Iskusstvo, pp. 191-220.

Petrukhin V.Ia., 2004. Mirovoe derevo. Slavianskie drevnosti: Etnolingvisticheskii slovar' [Slavic antiquities: Ethnolinguistic dictionary], vol. 3, Moscow: Izd-vo Mezhdunarodnye otnosheniia, pp. 253-254.

Rybakov B.A., 1994. lazychestvo drevnikh slavian [Paganism of ancient Slavs], Moscow: Nauka, 608 p.

Shaparova N.S., 2001. Kratkaia entsiklopediia slavianskoi mifologii [Short encyclopedia of Slavic mythology], Moscow: AST: Astrel: Russkie slovari, 624 p.

Toporov V.N., 1980. Drevo mirovoe. Mify narodov mira: Entsiklopediia: $V 2$ tomakh [Myths of people of the world: The encyclopedia: In 2 vol.], vol. 1, Moscow: Nauka, pp. 398-406.

Valentsova M.M., 2004. Priazha. Slavianskie drevnosti: Etnolingvisticheskii slovar' [Slavic antiquities: Ethnolinguistic dictionary], vol. 4, Moscow: Mezhdunarodnye otnosheniia, pp. 328-330. 